Laboratory

Analywod Chemistry

Laboratory

Analytual Chemistry

Laboratory

Anayulod Chemisty

Laboratory

Analytical Chemistry

Laboratory

Analytical Chemistry

Laboratory

Analytical Chemistry

Comparison of Acid Leachate and Fusion Methods to Determine Plutonium and Americium in

Laboratory
Analytical Chemistry

Analytical Chemistry

Laboratory

Analyoul Chemistry.

AUG 171992

by Lesa L. Smith, Francis Markun, and Tony TenKate

Analytical Chemistry

Laboratory

Analyical Chemistry

Laboratory

Analytical Chemistry

Laboratory

Analyical chemistry

Laboratory

Analytical chemistry

Laboralory

Analyical Chemistry

Laboratory

Analytical chemistry

Laboratory

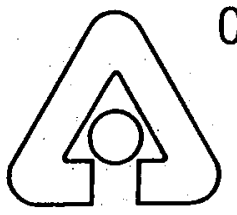

Chemical Technology Division

Argonne National Laboratory, Argonne, Illinois 60439

operated by The University of Chicago

for the United States Department of Energy under Contract W-31-109-Eng-38

Analylical chemistry

Laboratory

Analyical Chemistry

Laboratory

Analytical Chemistry

Laboratory

Analytical Chemistry

Laboratory 
Argonne National Laboratory, with facilities in the states of Illinois and Idaho, is owned by the United States government, and operated by The University of Chicago under the provisions of a contract with the Department of Energy.

\section{DISCLAIMER}

This report was prepared as an account of work sponsored by an agency of the United States Government. Neither the United States Government nor any agency thereof, nor any of their employees, makes any warranty, express or implied, or assumes any legal liability or responsibility for the accuracy, completeness, or usefulness of any information, apparatus, product, or process disclosed, or represents that its use would not infringe privately owned rights. Reference herein to any specific commercial product, process, or service by trade name, trademark, manufacturer, or otherwise, does not necessarily constitute or imply its endorsement, recommendation, or favoring by the United States Government or any agency thereof. The views and opinions of authors expressed herein do not necessarily state or reflect those of the United States Government or any agency thereof.

Reproduced from the best available copy.

Available to DOE and DOE contractors from the Office of Scientific and Technical Information P.O. Box 62

Oak Ridge, TN 37831

Prices available from (615) 576-8401

Available to the public from the National Technical Information Service

U.S. Department of Commerce

5285 Port Royal Road

Springfield, VA 22161 


\section{DISCLAIMER}

This report was prepared as an account of work sponsored by an agency of the United States Government. Neither the United States Government nor any agency Thereof, nor any of their employees, makes any warranty, express or implied, or assumes any legal liability or responsibility for the accuracy, completeness, or usefulness of any information, apparatus, product, or process disclosed, or represents that its use would not infringe privately owned rights. Reference herein to any specific commercial product, process, or service by trade name, trademark, manufacturer, or otherwise does not necessarily constitute or imply its endorsement, recommendation, or favoring by the United States Government or any agency thereof. The views and opinions of authors expressed herein do not necessarily state or reflect those of the United States Government or any agency thereof. 


\section{DISCLAIMER}

Portions of this document may be illegible in electronic image products. Images are produced from the best available original document. 


\section{Argonne National Laboratory 9700 South Cass Avenue Argonne, Illinois 60439}

\section{COMPARISON OF ACID LEACHATE AND FUSION METHODS TO DETERMINE PLUTONIUM AND AMERICIUM IN ENVIRONMENTAL SAMPLES}

$$
\text { by }
$$

Lesa L. Smith, Francis Markun, and Tony TenKate

PUPLICLY RELEASABLE
$\frac{B}{\text { Authorizing Official }}$
Date: $\quad 5-4-06$

June 1992 


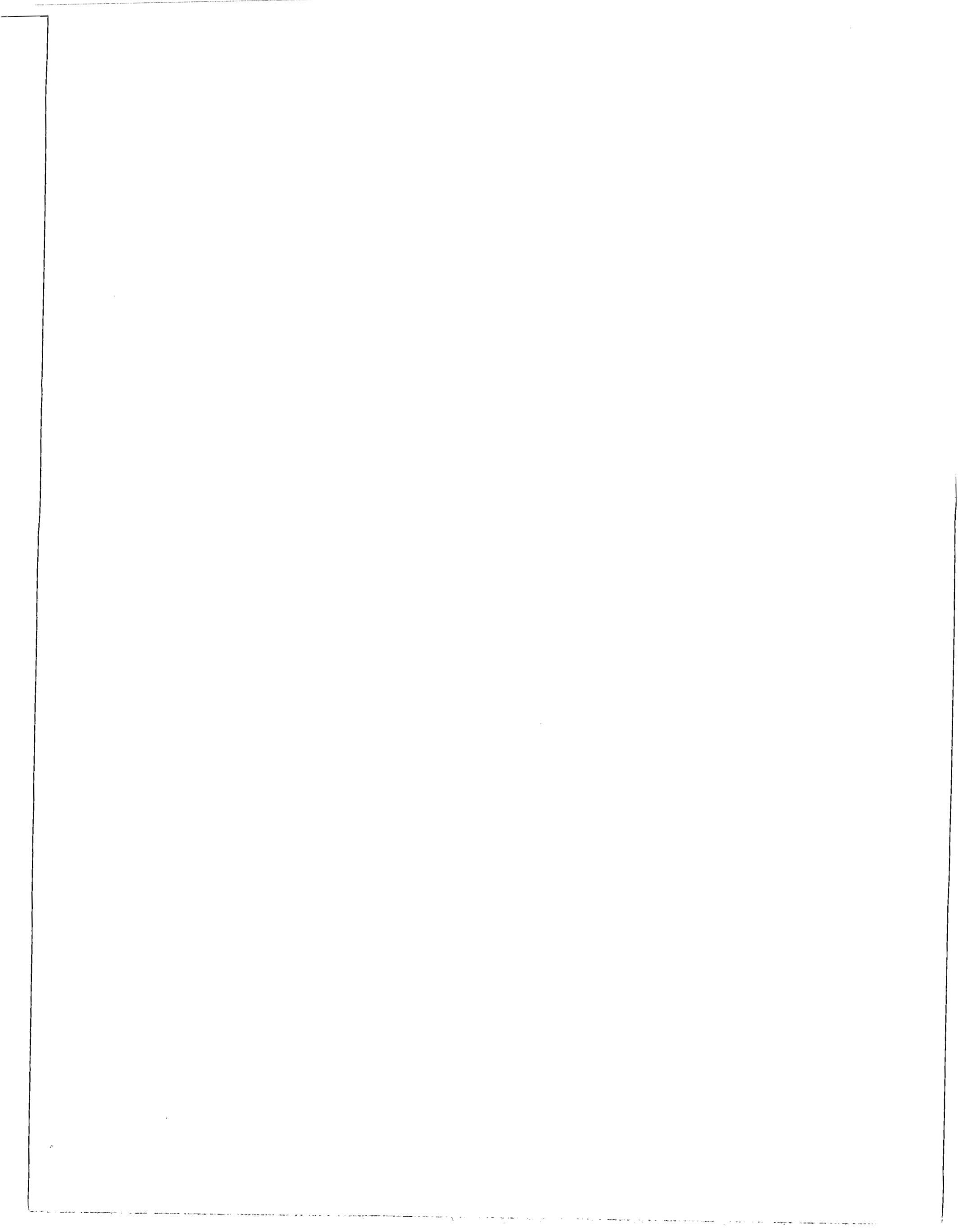




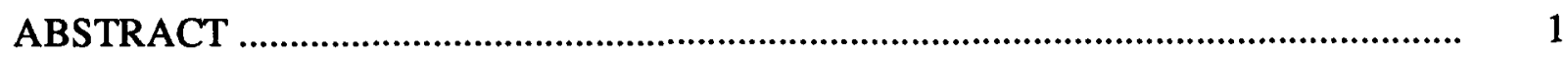

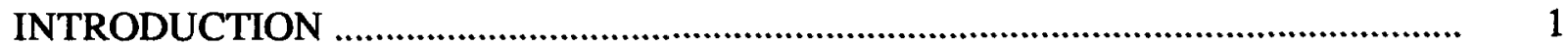

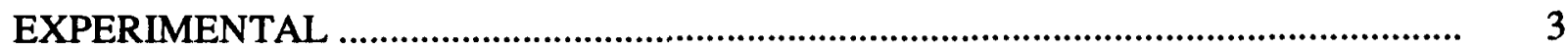

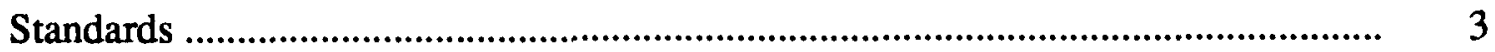

Sample Preparation ..................................................................................................... 3

Aqua Regia Leachate Method ................................................................................ 3

Potassium Fluoride-Pyrosulfate Fusion Method …………......................................... 4

Electrodeposition .............................................................................................. 5

RESULTS AND DISCUSSION ...............................................................................

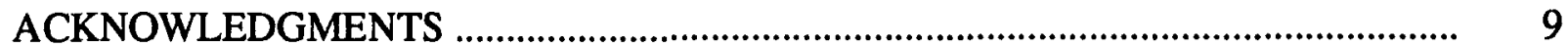

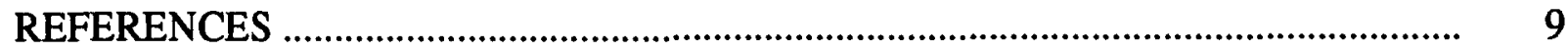




\section{LIST OF TABLES}

No.

Title

$\underline{\text { Page }}$

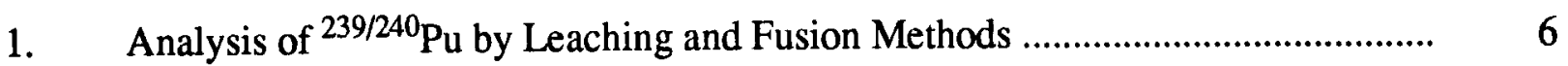

2. Analysis of ${ }^{241}$ Am by Leaching and Fusion Methods ..................................... 6

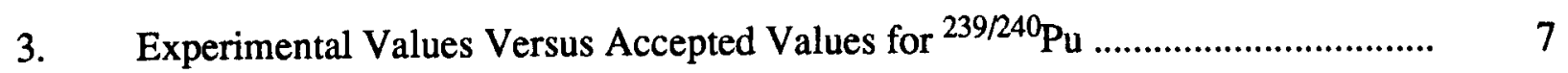

4. Experimental Values Versus Accepted Values for ${ }^{241}$ Am ................................ 8

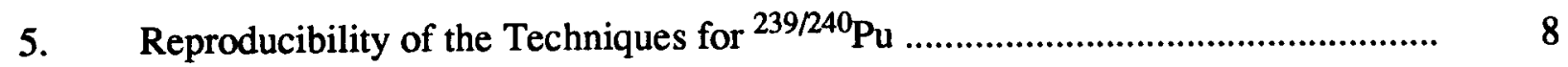

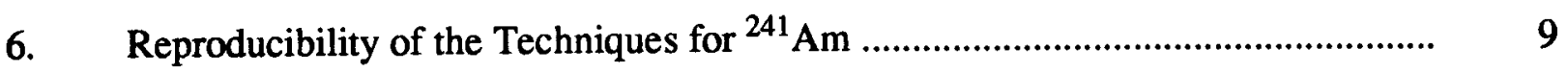




\title{
COMPARISON OF ACID LEACHATE AND FUSION METHODS TO DETERMINE PLUTONIUM AND AMERICIUM \\ IN ENVIRONMENTAL SAMPLES
}

by

Lesa L. Smith, Francis Markun, and Tony TenKate

\begin{abstract}
The Analytical Chemistry Laboratory at Argonne National Laboratory performs radiochemical analyses for a wide variety of sites within the Department of Energy complex. Since the chemical history of the samples may vary drastically from site to site, the effectiveness of any analytical technique may also vary. This study compares a potassium fluoride-pyrosulfate fusion technique with an acid leachate method. Both normal and high-fired soils and vegetation samples were analyzed for both americium and plutonium. Results show both methods work well, except for plutonium in high-fired soils. Here the fusion method provides higher accuracy.
\end{abstract}

\section{INTRODUCTION}

Sensitive and reliable analytical techniques to detect and measure actinides in environmental samples are increasingly important due to the expanding public scrutiny of the nuclear industry. Waste burial practices, as well as the impacts of both accidental and routine releases, need to be monitored to allay public concern. 
Actinides may enter the environment through several distinct pathways, such as fallout from nuclear testing, leakage from fuel fabrication or reprocessing complexes, and leaching from waste storage facilities. Furthermore, the chemical history of the sample substantially influences its chemical behavior. Plutonium from nuclear testing may exhibit different chemical behavior than plutonium derived from reprocessing or waste disposal. For example, plutonium oxide in the presence of silica or alumina becomes extremely refractory when heated strongly and consequently difficult to dissolve. ${ }^{1,2}$

Sill et al. ${ }^{3}$ contend that aqua regia acid leaching techniques are inadequate for samples requiring plutonium analyses. They assert that much of the activity can be left behind in the insoluble residue due to the possible refractory nature of these samples, and that a total dissolution or fusion technique is therefore always indicated. However, this method is very expensive, requiring excessive man-hours and creating large quantities of waste. Bishop et al. ${ }^{4}$ compared an acid leach procedure in which greater than $90 \%$ of the plutonium was removed from the soils with the potassium fluoride-pyrosulfate fusion method described by Sill et al. Bishop et al. found that leaching and fusion results essentially agreed for normal soils and that the acid leachate technique requires less analysis time and is therefore more cost-effective.

The Analytical Chemistry Laboratory (ACL) at Argonne National Laboratory (ANL) performs radiochemical analyses for a wide variety of sites within the Department of Energy (DOE) complex. Since the chemical histories of the samples received by the ACL may vary widely from site to site, the ACL must be confident that the chosen dissolution method is appropriate and provides its customers with quality results at reasonable costs. Therefore, ACL's standard repetitive aqua regia leaching technique, ${ }^{5}$ which differs from Bishop's technique, was 
compared with Sill's potassium fluoride-pyrosulfate fusion technique ${ }^{3}$ for both plutonium and americium.

\section{EXPERIMENTAL}

\section{$\underline{\text { Standards }}$}

The radionuclides of interest were quantified by isotope dilution employing National Institute of Standards and Technology (NIST) traceable radionuclides. NIST standard reference materials SRM 4350B-Columbia River Sediment and SRM 4353-Rocky Flats Soil \#1 were utilized in this study. Environmental Monitoring Laboratory (EML) round-robin soil and vegetation samples, $8803 \mathrm{SOACl}$ and $8803 \mathrm{VEACl}$, respectively, were also analyzed.

\section{Sample Preparation}

The samples were dried at $80^{\circ} \mathrm{C}$ for 120 hours. The soils were then milled and sieved to less than $\mathbf{2 0 0}$ mesh for homogeneity. EML samples were analyzed as received. Five to ten grams of sample were employed in each analyses.

\section{Aqua Regia Leachate Method}

The samples were slurried with deionized water during the addition of isotopic tracers and then placed in a drying oven to remove the excess water. The soils were then put in a muffle furnace at $510^{\circ} \mathrm{C}$ overnight to destroy any organic material present in the sample. The aqua regia leaching method requires that the samples boil in $6 \mathrm{~N} \mathrm{HCl}$ for approximately two hours. The acid is then separated from the soil by centrifuging. The solids are repetitively leached with fresh $6 \mathrm{~N} \mathrm{HCl}$, followed by aqua regia, until the color of the leachate clears. The combined leachate solutions are evaporated to incipient dryness, and the residue is redissolved in approximately 40 milliliters of $8 \mathrm{~N} \mathrm{HNO}_{3}$. 
The radionuclides of interest are then separated by anion exchange chromatography utilizing Bio-Rad AG 1-X8 resin (chloride form, 100-200 mesh). The plutonium and thorium are initially fixed on the column. Any thorium present is removed by eluting with 40 milliliters of concentrated $\mathrm{HCl}$. The plutonium is then eluted with 25 milliliters of a solution that is $0.1 \mathrm{~N} \mathrm{HCl}$ and $0.01 \mathrm{~N} \mathrm{HF}$. The major soil constituents such as calcium, iron, and phosphates, as well as uranium, americium, and the lanthanides, are not retained and pass directly through the column. This fraction is purified by repetitive oxalic acid precipitations. Uranium is removed through a phosphate coprecipitation of the tervalent actinides and the lanthanides. Finally, americium and the other tervalent actinides are separated from the lanthanide group elements on an ammonium thiocyanate ion exchange column.

\section{Potassium Fluoride-Pyrosulfate Fusion Method}

The total dissolution procedure employs a potassium fluoride-pyrosulfate fusion to ensure complete sample dissolution and volatilization of silicon as silica tetrafluoride. The fusion residue is dissolved in dilute hydrochloric acid, and the actinide and lanthanide groups are quantitatively coprecipitated with barium sulfate.

The americium and plutonium are then sequentially separated from an aluminum nitratenitric acid system employing 30\% Aliquot-336 (Aldrich Chemical Company, Inc.) in xylene as the extractant. In the primary extraction, the acid level is maintained high enough so that the tervalent actinides and the lanthanides do not extract into the organic layer, but remain in the aqueous layer. Thorium is removed from this organic layer with $10 \mathrm{~N} \mathrm{HCl}$. Finally, a solution of perchloric and oxalic acids is employed to strip the plutonium from the organic layer.

The original aqueous fraction, which contains the tervalent actinides including americium and the lanthanides, is treated with acid-deficient aluminum nitrate and then extracted with fresh 
$30 \%$ Aliquot-336 in xylene. The tervalent actinides and the lanthanides are back extracted with 8

$\mathrm{N} \mathrm{HNO}_{3}$. Finally, the tervalent actinides are chemically separated from the lanthanides on an ammonium thiocyanate ion exchange column.

\section{Electrodeposition}

The analytes of interest were electrodeposited onto 3/4-in. stainless steel disks prior to counting by alpha spectroscopy. A sodium sulfate/sodium bisulfate medium described by Kressin ${ }^{6}$ was utilized for electrodeposition.

\section{RESULTS AND DISCUSSION}

Normal soils, high-fired soils, and vegetation samples were analyzed in this study. Table 1 and Table 2 compare analytical results of the leach and fusion methods for ${ }^{239 / 240} \mathrm{Pu}$ and ${ }^{241} \mathrm{Am}$, respectively. The values reported are either a single analytical result or an averaged value of several determinations, as noted. The differences should reflect both differences in method as well as in sample. Clearly, the leaching method does not remove all of the plutonium from the matrix. However, for those samples that have not been high-fired, the two methods demonstrate relatively good agreement within statistical uncertainty. The refractory nature of the high-fired samples magnify the difference in the methods for plutonium analysis. The americium results exhibit relatively good agreement between both methods. 
Table 1. Analysis of ${ }^{239 / 240} \mathrm{Pu}$ by Leaching and Fusion Methods

\begin{tabular}{lcc}
\hline & \multicolumn{2}{c}{$234 / 240 \mathrm{Pu}, \mathrm{pCi} / \mathrm{g}( \pm 2 \sigma)^{\mathrm{a}}$} \\
\cline { 2 - 3 } Sample Type & Leach Method & Fusion Method \\
\hline EML Soil & $0.034(0.004)$ & $0.043(0.004)$ \\
EML Vegetation $^{\mathrm{b}}$ & $0.050(0.002)$ & $0.058(0.008)$ \\
NIST SRM 4350B & $0.011(0.004)$ & $0.014(0.006)$ \\
NIST SRM 4353 & $0.256(0.026)$ & $0.266(0.020)$ \\
Laboratory $_{\text {High-Fired Soil }}{ }^{\mathrm{b}}$ & $0.269(0.038)$ & $0.396(0.042)$ \\
Environmental & & $0.256(0.016)$ \\
High-Fired Soil & $0.167(0.016)$ & $5.716(0.288)$ \\
& $3.363(0.174)$ & $23.72(1.12)$ \\
& $22.49(1.12)$ &
\end{tabular}

${ }^{a}$ Uncertainty based upon propagation of counting statistical error.

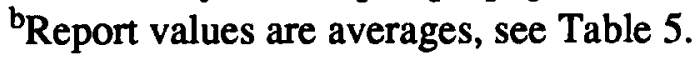

Table 2. Analysis of ${ }^{241} \mathrm{Am}$ by Leaching and Fusion Methods

\begin{tabular}{lll}
\hline & \multicolumn{2}{c}{${ }^{241} \mathrm{Am}, \mathrm{pCi} / \mathrm{g}( \pm 2 \sigma)^{\mathrm{a}}$} \\
\cline { 2 - 3 } Sample Type & Leach Method & Fusion Method \\
\hline EML Soil $^{\mathrm{b}}$ & $0.006(0.002)$ & $0.016(0.005)$ \\
EML Vegetation $^{\mathrm{b}}$ & $0.047(0.005)$ & $0.046(0.008)$ \\
NIST SRM 4353 & $0.069(0.008)$ & $0.042(0.016)$ \\
Laboratory & & \\
High-Fired Soil & $0.530(0.050)$ & $0.567(0.110)$ \\
Environmental & & \\
High-Fired Soil & $2.560(0.636)$ & $2.920(0.422)$ \\
& $0.015(0.012)$ & $0.006(0.004)$ \\
& $0.562(0.128)$ & $0.688(0.052)$
\end{tabular}

ancertainty based upon propagation of counting statistical error.

${ }^{\text {b }}$ Reported values are averages, see Table 6. 
To evaluate the accuracy and the precision of the two methods, standard environmental samples were analyzed. These data are presented in Tables 3-6. At the $99 \%$ confidence level, the experimentally determined values generally agree quite well with the accepted values. Our experimental values for NIST SRM 4353 are higher than expected, possibly due to the existence of hot particles in this material. As the data in Tables 5 and 6 demonstrate, the precision of both methods is generally quite good.

Differences between the two methods are most dramatic for the high-fired samples, as expected. However, both techniques are useful under certain circumstances. Clearly, the sample history, as well as the data quality objectives of a study, should play a significant role in the choice of analytical method. For environmental samples that have been high-fired and require high accuracy, the additional cost of a fusion method is warranted. However, for samples that have not been subjected to these extreme conditions, the less-expensive leach method is quite adequate.

Table 3. Experimental Values Versus Accepted Values for ${ }^{239 / 240} \mathrm{Pu}$

\begin{tabular}{llcc}
\hline & \multicolumn{3}{c}{${ }^{239 / 240} \mathrm{Pu}, \mathrm{pCi} / \mathrm{g}( \pm 3 \sigma)^{\mathrm{a}}$} \\
\cline { 2 - 4 } Sample Type & Leach Method & Fusion Method & Accepted Value \\
\hline EML Soil $^{\mathrm{b}}$ & $0.034(0.006)$ & $0.043(0.006)$ & $0.041(0.027)$ \\
EML Vegetation $^{\mathrm{b}}$ & $0.050(0.003)$ & $0.058(0.008)$ & $0.045(0.003)$ \\
NIST SRM 4350B & $0.011(0.006)$ & $0.014(0.009)$ & $0.014(0.003)$ \\
NIST SRM 4353 $^{\mathrm{b}}$ & $0.256(0.039)$ & $0.266(0.030)$ & $0.217(0.015)$ \\
\hline
\end{tabular}

${ }^{a}$ Uncertainty based upon propagation of counting statistical error.

${ }^{\mathrm{b}}$ Reported values are averages, see Table 5. 
Table 4. Experimental Values Versus Accepted Values for ${ }^{241} \mathrm{Am}$

\begin{tabular}{llcc}
\hline & \multicolumn{3}{c}{${ }^{241} \mathrm{Am}, \mathrm{pCi} / \mathrm{g},( \pm 3 \sigma)^{\mathrm{a}}$} \\
\cline { 2 - 4 } Sample Type & Leach Method & Fusion Method & Accepted Value \\
\hline NIST SRM 4353 & $0.069(0.012)$ & $0.042(0.024)$ & $0.034(0.003)$ \\
EML Soil $^{\mathrm{b}}$ & $0.006(0.003)$ & $0.011(0.008)$ & $0.007(0.003)$ \\
EML Vegetation $^{\mathrm{b}}$ & $0.047(0.008)$ & $0.058(0.012)$ & $0.046(0.006)$ \\
\hline
\end{tabular}

${ }^{a}$ Uncertainty based upon propagation of counting statistical error.

${ }^{b}$ Reported values are averages, see Table 6.

Table 5. Reproducibility of the Techniques for ${ }^{239 / 240} \mathrm{Pu}$

\begin{tabular}{|c|c|c|}
\hline \multirow[b]{2}{*}{ Sample Type } & \multicolumn{2}{|c|}{$239 / 240 \mathrm{Pu}, \mathrm{pCi} / \mathrm{g}( \pm 2 \sigma)^{\mathrm{a}}$} \\
\hline & Acid Leach Method & Fusion Method \\
\hline \multirow[t]{4}{*}{ EML Vegetation } & $0.051(0.002)$ & $0.054(0.006)$ \\
\hline & $0.049(0.002)$ & $0.062(0.004)$ \\
\hline & $0.050(0.002)$ & \\
\hline & Avg $=0.050(0.002)$ & Avg $=0.058(0.008)$ \\
\hline \multirow[t]{3}{*}{ SRM 4353} & $0.173(0.014)$ & $0.238(0.014)$ \\
\hline & $0.339(0.022)$ & $0.294(0.014)$ \\
\hline & Avg $=0.256(0.026)$ & $A v g=0.266(0.020)$ \\
\hline Laboratory & $0.259(0.026)$ & $0.390(0.030)$ \\
\hline \multirow[t]{2}{*}{ High-Fired Soil } & $0.279(0.028)$ & $0.402(0.028)$ \\
\hline & Avg $=0.269(0.038)$ & $\mathrm{Avg}=0.396(0.042)$ \\
\hline
\end{tabular}

${ }^{a}$ Uncertainty based upon propagation of counting statistical error. 
Table 6. Reproducibility of the Techniques for ${ }^{241} \mathrm{Am}$

\begin{tabular}{|c|c|c|}
\hline \multirow[b]{2}{*}{ Sample Type } & \multicolumn{2}{|c|}{${ }^{241} \mathrm{Am}, \mathrm{pCi} / \mathrm{g}( \pm 2 \sigma)^{\mathrm{a}}$} \\
\hline & Acid Leach Method & Fusion Method \\
\hline \multirow[t]{4}{*}{ EML Vegetation } & $0.046(0.006)$ & $0.039(0.008)$ \\
\hline & $0.048(0.006)$ & $0.062(0.010)$ \\
\hline & $0.048(0.006)$ & $0.054(0.008)$ \\
\hline & Avg $=0.047(0.005)$ & $\mathrm{Avg}=0.058(0.008)$ \\
\hline \multirow[t]{4}{*}{ EML Soil } & $0.006(0.002)$ & $0.006(0.002)$ \\
\hline & $0.005(0.002)$ & $0.009(0.004)$ \\
\hline & $0.007(0.002)$ & $0.017(0.008)$ \\
\hline & $\mathrm{Avg}=0.006(0.002)$ & Avg $=0.011(0.005)$ \\
\hline
\end{tabular}

${ }^{a}$ Uncertainty based upon propagation of counting statistical error.

\section{ACKNOWLEDGMENTS}

The authors would like to acknowledge the assistance of Charles Seils (ANL Chemical Technology Division) and Zhe-Zhong Shen (ANL Biological and Medical Research Division) in the completion of this work.

\section{REFERENCES}

1. Plutonium Handbook, O. J. Wick, Ed., Gordon and Breach, New York, (1967).

2. J. M. Cleveland, J. Inorg. Nucl. Chem. 26, 1470 (1964).

3. C. W. Sill et al., Simultaneous Determination of Alpha-Emitting Nuclides of Radium Through Californium in Soil, Anal. Chem. 46(12), 1725-1737 (1974).

4. C. T. Bishop et al., Comparison of a Leaching Method and a Fusion Method for the Determination of Plutonium-238 in Soil, Monsanto Research Corporation, Mound Laboratory, Miamisburg, OH (1971).

5. N. W. Golchert et al., Radiochem. Radioanal. Lett. 12(4-5), 215-221 (1972).

6. I. K. Kressin, Electrodeposition of Plutonium and Americium for High Resolution $\alpha$-Spectrometry, Anal. Chem. 49(6), 842-846 (May 1977). 
Distribution for ANL/ACL-92/2

Internal:

I. Ahmad

O. O. Ajayi

I. Ambats

D. V. Applegate

J. G. Asbury

R. W. Atcher

M. D. Atella

S. W. Ballou

A. Bandopadhyaya

R. W. Bane

D. A. Bass

J. K. Bates

J. E. Battles

C. A. Bebrich

N. J. Beskid

M. H. Bhattacharyya

S. K. Bhattacharyya

N. Bhatti

M. Blander

D. H. Bomkamp

A. S. Boparai

S. S. Borys

D. L. Bowers

B. S. Brown

F. A. Cafasso

Y. I. Chang

M. Clapper-Gowdy

R. B. Clare

S. M. Clark

J. H. Cleland

J. T. Collins

H. W. Conner

E. J. Croke

J. C. Cunnane

L. W. Deitrich

J. C. Demirgian

C. B. Dennis

M. H. Derbidge

D. R. Diercks

M. L. Dietz

J. D. Ditmars
H. Drucker

F. J. Dudek

B. D. Dunlap

A. J. Dvorak

W. L. Ebert

A. G. Engelkemeir

M. D. Erickson

A. M. Essling

W. D. Fairman

J. K. Fink

I. M. Fox

F. Y. Fradin

N. W. Golchert

A. J. Goldman

H. T. Goodspeed

D. G. Graczyk

D. W. Green

D. M. Gruen

W. H. Gunther

J. E. Harmon

W. Harrison

D. A. Haugen

R. R. Heinrich

J. E. Helt

W. F. Henning

J. E. Herceg

R. L. Herriford

I. Hlohowskyj

R. B. Holtzman

E. P. Horwitz

H.-S. Huang

E. Huberman

E. A. Huff

D. R. Huff

E. Y. Hwang

M. J. Janik

K. J. Jensen

D. O. Johnson

P. L. Johnson

T. R. Johnson

S. N. Kakar
T. F. Kassner

S. D. Kent

C. E. Klotz

A. J. Kras

A. R. Krauss

J. R. Krsul

M. Lachman

J. Laidler

L. L. Lamoureux

D. Larsen

S. L. Lawrence

K. H. Leong

L. G. LeSage

M. A. Lewis

P. C. Lindahl

M. J. Lineberry

C. D. Livengood

C. D. O. Loureiro

J. F. Marchaterre

F. Markun

V. A. Maroni

J. J. Marr

F. J. Martino

J. R. McCreary

H. F. McFarlane

C. A. Melendres

V. A. Mendez (10)

D. E. Moncton

L. R. Morss

T. P. Mulcahey

K. M. Myles

H. W. Myron

Z. Nagy

B. W. Nashold

L. A. Neimark

D. M. Nelson

P. A. Nelson

R. D. Nixon

J. W. O'Kelley

Y. Orechwa

K. A. Orlandini 


$\begin{array}{lll}\text { K. J. Parish } & \text { G. K. Shenoy } & \text { D. Tomasko } \\ \text { J.-H. Park } & \text { J. G. Sleeth } & \text { Z. Tomczuk } \\ \text { D. C. Parzyck } & \text { D. L. Smith } & \text { R. E. Toohey } \\ \text { T. L. Patton } & \text { D. L. Smith } & \text { A. Travelli } \\ \text { C. V. Pearson } & \text { F. P. Smith } & \text { Y. Tsai } \\ \text { D. R. Pedersen } & \text { L. L. Smith (5) } & \text { J. P. Unik } \\ \text { M. J. Pellin } & \text { R. K. Smither } & \text { R. A. Valentin } \\ \text { M. Petrick } & \text { C. T. Snyder } & \text { G. F. Vandegrift } \\ \text { K. C. Picel } & \text { R. W. Springer } & \text { R. Venkatadri } \\ \text { D. S. Poa } & \text { B. Srinivasan } & \text { K. S. Vorres } \\ \text { R. B. Poeppel } & \text { R. E. Stajdohar } & \text { D. C. Wade } \\ \text { A. J. Policastro } & \text { V. C. Stamoudis } & \text { L. C. Walters } \\ \text { Y. L. Qian } & \text { M. J. Steindler } & \text { D. W. Warren } \\ \text { A. C. Raptis } & \text { C. M. Stevens } & \text { D. P. Weber } \\ \text { E. G. Rauh } & \text { L. M. Stock } & \text { R. W. Weeks } \\ \text { D. M. Ray } & \text { W. E. Streets } & \text { M. L. Wesely } \\ \text { G. T. Reedy } & \text { K. Sugano } & \text { J. M. Williams } \\ \text { C. A. Reilly } & \text { T. M. Sullivan } & \text { R. E. Winans } \\ \text { M. J. Robinet } & \text { T. G. Surles } & \text { R. D. Wolson } \\ \text { B. J. Roop } & \text { W. M. Swift } & \text { J. L. Woodring } \\ \text { L. E. Ross } & \text { T. A. Taiwo } & \text { J. J. Wray } \\ \text { C. S. Sabau } & \text { B. S. Tani } & \text { R. A. Wynveen } \\ \text { N. A. Sacco-Gibson } & \text { J. D. Taylor } & \text { J. S. Yaeger } \\ \text { N. F. Sather } & \text { L. B. TenKate } & \text { R. K. Yoo } \\ \text { W. W. Schertz } & \text { T. TenKate } & \text { ANL Patent Dept. } \\ \text { A. Schriesheim } & \text { R. J. Teunis } & \text { ANL Contract File } \\ \text { W. J. Shack } & \text { C. E. Till } & \text { TIS Files (3) } \\ & & \\ \text { M } & & \end{array}$

External:

DOE-OSTI (2)

ANL Library (2)

Manager, Chicago Operations Office, DOE

T. A. Baillieul, DOE-CH

J. C. Haugen, DOE-CH

A. L. Taboas, DOE-CH-AAO

Chemical Technology Division Review Committee Members:

S. Baron, Brookhaven National Laboratory, Upton, NY

D. L. Douglas, Consultant, Bloomington, $\mathrm{MN}$

N. Jarrett, Noel Jarrett Associates, Lower Burrell, PA

J. G. Kay, Drexel University, Philadelphia, PA

J. Stringer, Electric Power Research Institute, Palo Alto, CA

J. B. Wagner, Arizona State University, Tempe, AZ

R. G. Wymer, Oak Ridge National Laboratory, Oak Ridge, TN 
A. Alford-Stevens, U.S. Environ. Protection Agency, Cincinnati, $\mathrm{OH}$

T. Beasley, U. S. Environmental Measurements Lab., New York, NY

J. Bennett, EG\&G Idaho, Inc., Idaho Falls, ID

R. E. Berkeley, U.S. Environ. Protection Agency, Research Triangle Park, NC

C. D. Bingham, New Brunswick Laboratory, Argonne, IL

D. Bogen, USDOE, New York, NY

N. F. Christopher, Martin Marietta Energy Systems, Piketon, $\mathrm{OH}$

G. Clark, Reynolds Electric \& Engineering, Las Vegas, NV

C. E. Coffey, Westinghouse Savannah River Co., Aiken, SC

P. T. Cunningham, Los Alamos National Laboratory, Los Alamos, NM

J. L. Daniel, Battelle Pacific Northwest Laboratory, Richland, WA

H. J. Dewey, Los Alamos National Laboratory, Los Alamos, NM

D. A. Dodd, Westinghouse Hanford Co., Richland, WA

J. G. Donnon, Savannah River Plant, Aiken, SC

J. G. Dorsey, Martin Marietta Energy Systems, Oak Ridge, TN

L. P. Duffy, USDOE, Environ. Restoration \& Waste Manage., Washington, DC

P. A. Duhamel, USDOE, Health and Environmental Research, Germantown, MD

C. Elly, U. S. Environmental Protection Agency, Chicago, IL

D. J. Fauth, Analytical Lab West Valley Nuclear Services, West Valley, NY

C. Fellers, Mound Laboratory, Miamisburg, $\mathrm{OH}$

R. B. Fitts, Oak Ridge National Laboratory, Oak Ridge, TN

C. W. Frank, USDOE, Office Technology Development, Germantown, MD

V. Gill, Westinghouse, Cincinnati, $\mathrm{OH}$

J. Goldstein, USDOE, Health and Environmental Research, Germantown, MD

T. C. Greengard, Rocky Flats Plant, Golden, CO

J. Harness, USDOE, Morgantown Energy Technology Center, Morgantown, WV

D. L. Herman, Westinghouse Materials Company of Ohio, Cincinnati, $\mathrm{OH}$

D. Hunter, Rockwell International, Golden, $\mathrm{CO}$

W. R. Jacobsen, Westinghouse Savannah River Co., Aiken, SC

W. Killian, Ferris State University, Big Rapids, MI

P. Krey, USDOE, Environmental Measurements Labs, New York, NY

J. M. Latkovich, Battelle Pacific Northwest Laboratory, Richland, WA

R. G. Lewis, U.S. Environ. Protection Agency, Research Triangle Park, NC

L. C. Lewis, Westinghouse Idaho Nuclear Company, Idaho Falls, ID

D. Lillian, USDOE, Office of Technology Development, Washington, DC

H. Lucas, Sedona, AZ

R. M. Lugar, EG\&G Idaho, Inc., Idaho Falls, ID

C. Marcelo, New Brunswick Laboratory, Argonne, IL

W. A. McClenny, U.S. Environ. Protection Agency, Research Triangle Park, NC

S. Messenger, Morton Arboretum, Lisle, $\mathbb{L}$

R. W. Morrow, Martin Marietta Energy Systems, Oak Ridge, TN

J. D. Mulik, U.S. Environ. Protection Agency, Research Triangle Park, NC

R. Norman, Gas Research Institute, Chicago, IL

R. Ohlinger, Westinghouse Materials Company of Ohio, Cincinnati, $\mathrm{OH}$

R. D. Oldham, New Brunswick Laboratory, Argonne, II

J. Phillips, Los Alamos National Laboratory, Los Alamos, NM 
J. D. Pleil, U.S. Environ. Protection Agency, Research Triangle Park, NC

F. Podosek, Washington University, St. Louis, MO

J. W. Pyper, Lawrence Livermore National Laboratory, Livermore, CA

J. M. Ramirez, Allied-Signal, Inc., Kansas City, MO

R. Scott, USDOE, Environmental Audit and Compliance, Washington, DC

J. Q. Searcy, Sandia National Laboratories, Albuquerque, NM

W. D. Shults, Oak Ridge National Laboratory, Oak Ridge, TN

J. Smith, University of Chicago, Chicago, IL

J. R. Stetter, Transducer Research, Inc., Palos Hills, IL

F. D. Stevenson, USDOE, Basic Energy Sciences, Germantown, MD

C. Stroup, Westinghouse Hanford Company, Richland, WA

N. Trahey, New Brunswick Laboratory, Argonne, IL

R. Villarreal, Los Alamos National Laboratory, Los Alamos, NM

H. A. Vincent, U.S. Environmental Protection Agency, Las Vegas, NV

W. M. Walsh, Health Research Institute, Wheaton, IL

W. C. Weimer, Battelle Pacific Northwest Laboratory, Richland, WA

R. P. Whitfield, USDOE, Environmental Restoration, Washington, DC

C. G. Whitworth, Jr., MSE, Inc., Butte, MT

R. J. Wingender, Gurnee, IL

P. D. Wooldridge, Paducah Gaseous Diffusion Plant, Paducah, KY

J. Zarret, EG\&G Rocky Flats Plant, Golden, CO 